Federal Reserve Bank of Minneapolis

Research Department

\title{
An Evaluation of the Performance of an Applied General Equilibrium Model of the Spanish Economy
}

\author{
Timothy I. Kehoe, Clemente Polo, \\ and Ferran Sancho*
}

Working Paper 480

Revised October 1994

\begin{abstract}
In 198586 the authors were members of a team that constructed a static applied general equilibrium model that was used to analyze the impect on the Spenish economy of the 1986 fiscal reform, which sccompanied Spain's entry into the European Comnunity. This paper compares the results obtained to recently published data for 198587 ; we find that the model performed well in predicting the changes in relative prices and resource allocation that actually occurred, particularly if we incorporate exogenous shocks that affected the Spanish economy in 1986. We also analyze the sensitivity of the results to alternative specifications of the labor market and macroeconomic closure rules; we find that the central results are robust.
\end{abstract}

*Keboe, University of Minnesatn, Federal Reserve Bank of Minnenpolis, and Universitat Autonome de Barcelona; Polo and Sancho, Universitat Autbnoma de Barcelone. Wo gratefully acknowledge financial aupport from NSF Grant SES 8922036 (Kehoe) and CICYT Grant PB 890309 (Polo and Sancho). Wh thank participants at the IIASA Applied General Equilibrium Conference, Laxenburg, Austria, August 1991, the International Trade Workstop at UCLA, March 1992, and the Grachate Public Finance Course at the University of Minnesota, Winter 1993, Betry Caucutt, and Ed Prescott for helpful suggestions. Abowe all, we wish to thank our colleagues who have worked with us on the MEGA (Model d'Equilibri General Aplicat) Project at the Universitat Autònoma de Barcelona: Antonio Manresa, Pedro Javier Noyola, Jaime Serra-Puche, Cristina Echevarrfa, Walter Garcí, Ana Laborda, and Xavier Ramirez. The viows expressed herein are those of the authors and not necessarily those of the Federal Reserve Bank of Minneapolis or the Federal Reserve System. 


\section{Introduction}

In 1985-86 the authors were members of a team that constructed a static applied general equilibrium model of the Spanish economy. This model was used to analyze the impact on the Spanish economy of the fiscal reform implemented on January 1, 1986, to accompany Spain's entry into the European Community. The principal ingredient of these reforms was the introduction of a value-added tax (VAT) on consumption to replace a complex range of indirect taxes, including a turnover tax applied at every stage of the production process. The results obtained in this analysis have been issued as working papers or published in a variety of outlets (see Kehoe, Manresa, Noyola, Polo, Sancho, and Serra-Puche 1985a, 1986a, 1986b; Kehoe, Manresa, Noyola, Polo, and Sancho 1988; and Kehoe, Manresa, Polo, and Sancho 1989).

Using recentily published data, we compare the results generated by the model to the changes that actually occurred in Spain during the period 1985-87. We also analyze the robustness of the results to alternative specifications of labor market adjustment and macroeconomic closure. We find that the model performs well on both scores. The model performs well in predicting the changes that actually occurred. This is particularly true if we incorporate two major exogenous shocks that hit the Spanish economy in 1986: a sharp fall in the price of petroleum imports and a decline in productivity in the agricultural sector due mostly to weather conditions. Furthermore, the central results concerning changes in relative prices and resource allocation are remarkably robust to different labor market specifications and to different macro closure rules.

Applied general equilibrium models have been used extensively over the past two decades to analyze the impact of economic policy; see, for example, Scarf and Shoven (1984); Piggott and Whalley (1985); and Bergman, Jorgenson, and Zalai (1990); and Mercenier and Srinivasan. Although a large amount of energy and resources has gone into constructing applied general equilibrium models and using them to perform policy analyses, it is surprising how little effort has 
gone into doing the sort of ex post performance evaluation that we do here. Many economists seern to think that various shortcomings of applied general equilibrium models-lack of data, simplicity of specification, sensitivity to macroeconomic closure rules, problems of interpretation in terms of time, and so on-make them unsuitable for accurate prediction. This view seems to be sometimes adopted by applied general equilibrium researchers themselves. Whalley (1985) clearly expresses the uneasiness felt by many applied general equilibrium modelers about comparing there results with data:

Since the essence of theory is simplification which in an exact sense must be wrong, the constraints of tractability perhaps dictate that economic theory can ultimately be only an organizational framework for thinking about economic problems. . . . Do we rely only on statistical tests or do we allow judgement to enter? Are we willing to examine our perceptions of ourselves and our social institutions in the belief that this is what shapes our policymaking, rather than limit ourselves merely to attempting to track an often illusive reality?

This paper takes a strong stand against this reluctance to compare results with data. Only by showing that a model can replicate and, to some extent, predict the principal developments that take place in the economy that it intends to represent can we justify the effort put into a large-scale quantitative model. The predictions that an applied general equilibrium model makes are conditional predictions: they predict the impact of a change in some exogenous variables conditional on other exogenous variables remaining constant. Over the period 1985-87, significant shocks-besides the policy changes originally included in the modeling experiment-buffeted the Spanish economy, which we need to take into account when evaluating the accuracy of the prediction. A major advantage of using a detailed structural model like that analyzed here is that exogenous shocks can be incorporated in an obvious way.

Our approach is related to that of Johansen (1960, Chapter 8), Dervis, de Melo, and Robinson (1982, Chapter 10); Devarajan and Sierra (1986); and Parmenter, Meagher, McDonald, and Adams (1990), who investigate how well their models do in tracking the impact of policy changes and 
external shocks after these changes have occurred. In addition, however, we report some results that were, at the time they were made, pureiy predictions.

One explanation for the relative accuracy of the predictions of the Spanish model is that the fiscal reform of 1986 was the ideal sort of policy change for this type of model to analyze: it had a major effect on relative prices and resource allocation but did not seem to have had an impact on intertemporal decision making that was impossible to capture in a static framework. It should be stressed that the research team that constructed this model never intended it to predict, nor thought it capable of predicting, changes in the economic growth rate or the rate of inflation; see, for example, Kehoe et al. (1986b, 1988).

\section{The Model}

We now present a brief description of the model that focuses on the alternatives for the specification of the labor market and for macroeconomic closure rules. The model is of the type originally developed by Shoven and Whalley (see Shoven and Whalley 1984 for a survey). It is a very simple static general equilibrium model, which has been calibrated to data for 1980 , the latest year for which data was available at the time. Kehoe et al. (1988b) provide the dataset. A more complete description of the model can be found in Kehoe et al. (1989).

There are four types of people in the model: producers, consumers, the government, and foreign sectors. There are 12 production sectors; 11 of them produce private goods and services, and the final one produces government services, which we aiso call the public good. The output of these sectors is combined in fixed proportions to produce 12 goods: 9 consumption goods, an investment good, and 2 types of expors, those demanded by the EC and those demanded by the rest of the world (ROW).

A distinction between production goods and consumption goods is necessary because the national accounts and the input-ouput table classify goods in a different way than do the survey of 
family budgets and the index of consumer prices. The food and nonalcoholic beverages category in the consumption goods classification, for example, combines goods from the agriculture, food products, commerce, and transportation categories in the production goods classification, while the agricuiture category in the production goods classification is divided up into goods in the food and nonalcoholic beverages, housing, and recreational services categories in the consumption goods classiffcation. A list of the different goods, together with the corresponding categories in the data sources, is presented in Table 1 .

\section{Producers}

The technology of the twelve production sectors is represented by nested constant-returns production functions. Total output is a Cobb-Douglas aggregate of domestic output and imports of equivalent products, which is a variant of Armington's (1969) assumption. Domestic output is produced by combining in fixed proportions intermediate products and value added. Value added, in turn, is a Cobb-Douglas aggregate of the three factors of production: skilled labor, unskilled labor, and capital. We assume producers choose inputs to minimize production costs.

The unitary elasticity of substitution between domestic output and imports may seem low. Unpublished econometric research conducted as part of the MEGA project suggests that it is not. Shiells and Reinert (1993) also find empirical evidence that this elasticity may be one, or even less. (Standard commodity classifications, even at a fairly disaggregated level, probably lump together different goods in a way that invalidates any intuition about the high degree of substitutability between the domestic and the imported version of the same good.)

\section{Consumers}

On the consumption side, there are eight representative consurners. Each consumer is an aggregate of all households whose family head is within a socioeconomic group defined by his or her 
Table 1

List of Sectors

\begin{tabular}{ll}
\hline \multicolumn{2}{c}{ Production Goods } \\
\hline Model & Input-Output Table \\
\hline 1. Agriculture & $1-4$ \\
2. Energy & $5-9$ \\
3. Basic Industry & $10-23$ \\
4. Machinery & $24-29,31-34$ \\
5. Automobile Industry & 30 \\
6. Food Products & $35-49$ \\
7. Other Manufacturing & $50-62$ \\
8. Construction & 63 \\
9. Commerce & $64-66$ \\
10. Transportation & $67-73$ \\
11. Services & $74-81,85(1 / 2)$ \\
12. Government Services & $82-84,85(1 / 2)$ \\
\hline
\end{tabular}

Consumption Goods

\begin{tabular}{ll}
\hline Model & Consumer Expenditure Survey \\
\hline 1. Food and Nonalcoholic Beverages & $111-121$ \\
2. Tobacco and Alcoholic Beverages & $131,141,142$ \\
3. Clothing & $211-222$ \\
4. Housing & $311-324$ \\
5. Household Articles & $411-461$ \\
6. Medical Services & $511-551$ \\
7. Transportation & $611-642$ \\
8. Recreational Services & $711-741$ \\
9. Other Services & $811-924$ \\
\hline \hline
\end{tabular}

'Corresponding eategories in Contabilidad Nacional de Espasa, Base 1980, Cuentas Nacionales y Tabla Input-Oupue.

${ }^{2}$ Correponding categories in Encuerta de Presupuerras Farriliares, 1980-81. 
age, level of education, and income. A list of the different consumers can be found in Table 2 . Preferences are represented by Cobb-Douglas utility indices defined over the nine consumption goods and savings. Since utility functions are Cobb-Douglas, introducing savings in this way is equivalent to assuming that each consumer saves a constant fraction of after-tax income. It is this way of modeling savings behavior, rather than having it be the solution to an intertemporal optimization problem, that essentially distinguishes this as a static model.

Each consumer has an endowment of productive factors that he supplies inelastically; the sales of these factors determine his gross income. Disposable income is determined by a complex set of government taxes and transfers (medical transfers, social security, unemployment compensation, and other current and capital transfers). Consumers maximize their utility functions subject to their budget constraints.

\section{Labor Markets}

Labor demand is determined by producers to minimize costs and to meet demand for goods. Unemployment arises when the induced demand for labor is not enough to hire all labor supplied by workers. We have already mentioned that labor is inelastically supplied. More specifically, we assume that workers, or unions, fix the real wage and that all labor available is supplied at this wage, although not all is demanded. The real wage fixed depends on the unemployment rate, so that, in equilibrium, the following condition is satisfied in each of the two labor markets:

$$
\omega_{i}=\left[\left(1-u_{i}\right) /\left(1-\bar{u}_{i}\right)\right]^{1 / \beta} \text {. }
$$

Here $\omega_{\mathrm{i}}$ is the real wage, the nominal wage divided by an appropriate consumer price index, for either unskitled labor or skilled labor; $u_{i}$ is the unemployment rate in the corresponding labor market; $\bar{u}_{\mathrm{i}}$ is the corresponding benchmark unemployment rate; and $\beta$ is a nonnegative parameter that measures 
Table 2

List of Consumer Groups

\begin{tabular}{|c|c|c|}
\hline Age of Household Head & 1980 Income & $\begin{array}{l}\text { Education of } \\
\text { Household Head }\end{array}$ \\
\hline 1. 24 years or less & less than 700,000 pesetas & \\
\hline 2. 24 years or less & more than 700,000 pesetas & \\
\hline 3. between 25 and 65 years & less than $1,000,000$ pesetas & no higher \\
\hline 4. between 25 and 65 years & more than $1,000,000$ pesetas & no higher \\
\hline 5. between 25 and 65 years & less than $1,000,000$ pesetas & some higher \\
\hline 6. between 25 and 65 years & more than $1,000,000$ pesetas & some higher \\
\hline 7. 66 years or more & less than 700,000 pesetas & $\cdot$ \\
\hline 8. 66 years or more & more than 700,000 pesetas & \\
\hline
\end{tabular}


the sensitivity of real wages to unemployment. (There is, of course, another interpretation of this specification in terms of an elastic supply of labor.)

As $\beta$ approaches infinity, the real wage approaches one, its benchmark value. We call this extreme case "rigid wages" to indicate that real wages are unchanged and the unemployment rate varies. At the other extreme, as $\beta$ approaches zero, the unemployment rate approaches its benchmark value. We refer to this case as "flexible wages" to indicate that real wages adjust to maintain the benchmark unemployment rate. As $\beta$ goes from zero to infinity, the real wage becomes less sensitive to unemployment. A recent study of the Spanish labor market by Andres, Dolado, Molinas, Sebastian, and Zabalza (1988) suggests $\beta$ would be 1.5. Accepting this value, we see that a 1 percentage point increase in the unemployment rate (an increase to 12.53 percent from its 11.53 percent 1980 benchmark value) would reduce the real wage by 0.75 percent.

\section{The Government: Macroeconomic Closure Alternatives}

The role of the government is complex and affects the allocation of resources in several ways. We have already mentioned that the government produces public goods. The government can also be viewed as a consumer that demands public goods and investment. It derives income from its endowment of capital and from taxes. Income, production, consumption, social security, and import taxes are included in the model. The government uses its income to finance its purchases of goods and services (government services and investment) and its transfers to consumers. The difference between total revenues and expenditures determines the public surplus or deficit. The model satisfies the macroeconomic identity that private savings is equal to private investment plus the government deffeit minus the trade deficit with the EC and ROW.

The model allows some fexibility in choosing the variables that are exogenous and endogenous. Thus, the government deficit can be endogenous or exogenous. In the first case, the activity level of the government is fixed, while in the second the activity level is endogenous. This flexibility 
allows us to answer two different questions: What would be the government deffit when the government activity level is arbitrarily fixed? and, What would be the variation needed in the government activity level to achieve a given government deficit target?

\section{The Foreign Sectors: Macroeconomic Closure Alternatives}

We also have the option of making exports to the EC and exports to the ROW exogenous or endogenous. If exports to the EC are exogenously fixed, for example, then, since imports to the EC are endogenously determined, so is the trade deficit with the EC. In contrast, if the trade deficit is arbitrarily fixed, then exports are endogenous.

We, therefore, have three options: to have the government deficit endogenous or exogenous, and to make each of the trade deficits endogenous or exogenous. There are potentially, therefore, eight $\left(=2^{3}\right)$ different macroeconomic closure rules. There are additional possibilities for macroeconomic closure that involve making investment exogenous; we do not consider such closure rules here.

\section{Equilibrium}

The deffnition of equilibrium varies with the macroeconomic closure rule. Consider, for exampic, the case where the government and foreign sector deficits are endogenous. An equilibrium then is given by a vector of prices, activity levels, unemployment rates, government revenues, and government and trade deffcits, such that (1) consumers maximize utility subject to their budget constraints, (2) producers obtain zero after-tax profits, (3) government revenue plus government deficit equals government spending, (4) the value of imports mimus the value of exports equals the trade deficit for each of the two trading areas, (5) all markets except labor markets clear, and (6) the real wage-unemployment relations are satisfied. 


\section{Comparisons with Actual Data 1985-87}

Spain's 1986 entry into the European Community was accompanied by two major government policy reforms. The first, and most significant, policy reform introduced a consumption value added tax to replace the previous indirect tax system. The second policy reform reduced trade barriers against imports from other EC countries. In contrast with the fiscal policy reform, which took place immediately, the trade policy reform was scheduled to be phased in gradually over six years. The part of the reform that took place in 1986 mostly involved changes in tariff rates. Kehoe et al (1985a, 1986a, 1986b, 1988, 1989) incorporate the tax and tariff parameters that correspond to both these policy reforms into the model described in the previous section. It should be stressed, however, that the parameter changes involved in the tax reform are far larger than those involved in the trade reform.

In this section we confront the results generated by the model with the data that describe the changes that actually took place in the Spanish economy during the periods 1985-86 and 1985-87. It is changes over this one- or two-year time horizon that the authors feel this type of model can capture. On one hand, it can be argued that this time horizon is long enough so that there can be enough gestation or depreciation of capital stocks in each sector to justify assuming mobility of capital, at least as long as changes in capital utilization by sector are less than, say, 10 percent. On the other hand, it can be argued that this time horizon is short enough to justify ignoring secular trends and the intersectoral impact of changes in the growth rate.

As we have mentioned, the model was not designed to predict changes in inflation or in the growth rate. Consequently, in reporting both the simulation results and the actual data, we deflate by an appropriate price or output index. In the case of consumer prices and industrial activity levels, this procedure produces changes whose weighted average is zero. Dividing consumer prices by a consumer price index based on consumption expenditure shares by sector, for example, produces 
changes that sum to zero when weighted by these expenditure shares. Similarly, we obtain changes in industrial activity levels that sum to zero when weighted by value added shares by sector. In the case of producer prices, however, prices are normalized using the consumer price index rather than by a producer price index. Although this treatment of producer prices is somewhat asymmetric, it is useful because it makes it easy to compare the changes in the relative prices of consumer goods and producer goods. The change in the producer price index relative to that in the consumer price index can be recovered by summing the changes in producer prices weighted by value of production shares by sector. In all three cases, the weights used in the different indices are taken from the 1980 social accounting matrix constructed by Kehoe et al. (1988b) that provides the database for the model. Since the model has been calibrated to a different year than the year in which the tax reform took place, the choice of weights is somewhat arbitrary. Fortunately, calculations not reported here indicate that the results are not sensitive to this choice.

Tables 3-6 present the actual changes that occurred in the Spanish econony over the periods 1985-86 and 1985-87 in terms of consumer prices, producer prices, activity levels, and macroeconomic aggregates. Because of limited data on the changes that actually took place in 1986 and 1987, we report changes in producer prices and activity levels for only a subset of producer prices and activity levels. We also report the simulation results for the case where government and foreign deficits are endogenous and where $\beta=1.5$. As we shall see, the results are not very sensitive to this closure rule nor to this specification of labor market behavior.

Examining the actual changes that took place over 1985-86, we see a substantial increase in indirect tax rates. This increase manifests itself in the sharp decline in the relative prices of producer goods, reported in the first column of Table 4, compared to those of consumer goods, reported in the first column of Table 3. This change in relative prices is to be expected since the VAT largely exempts producer goods from taxes. The increase in indirect taxes can also be seen in the changes 
Table 3

Consumer Prices

(Percentage Change ${ }^{l}$ )

\begin{tabular}{lccrcr}
\hline Sector & $\begin{array}{c}\text { Actual } \\
1986 / 1985^{2}\end{array}$ & $\begin{array}{c}\text { Actual } \\
\text { 1987/1985 }\end{array}$ & $\begin{array}{c}\text { Model } \\
\text { Policy Only }\end{array}$ & $\begin{array}{c}\text { Model } \\
\text { Model } \\
\text { Shocks Only }\end{array}$ & $\begin{array}{c}\text { Policy and } \\
\text { Shocis }\end{array}$ \\
\hline 1. Food and Nonalcoholic Beverages & 1.8 & -.7 & -2.3 & 4.0 & 1.7 \\
2. Tobacco and Alcoholic Beverages & 3.9 & 5.3 & 2.5 & 3.1 & 5.8 \\
3. Clothing & 2.1 & 5.6 & 5.6 & .9 & 6.6 \\
4. Housing & -3.2 & -3.9 & -2.2 & -2.7 & -4.8 \\
5. Household Articles & .1 & -1.0 & 2.2 & .7 & 2.9 \\
6. Medical Services & -.7 & .4 & -4.8 & .6 & -4.2 \\
7. Transportation & -4.0 & -2.6 & 2.6 & -8.8 & -6.2 \\
8. Recreation & -1.4 & -1.0 & -1.3 & 1.4 & .1 \\
9. Other Services & 2.9 & 4.5 & 1.1 & 1.7 & 2.8
\end{tabular}

Change in Consumer Price Index

Weighted Correlation with 1986/1985

Weighted Correlation with 1987/1985
8.4

1.000

.749
13.5

.749

1.000
.0

$-.079$

.497

Prediction $R^{2}$ for $1986 / 1985^{5}$

.424

$-.995$

.226

.657

Prediction $R^{2}$ for 1987/1985

.540

.142

${ }^{1}$ Change in sectoral price index defsted by the consumer price index. The weights used are the consumption ahares (1) 0.2540, (2) 0.0242, (3) $0.0800,(4) 0.1636,(5) 0.0772,(6) 0.0376,(7) 0.1342$, (8) 0.0675 , and (9) 0.1617 .

${ }^{2}$ Actual data are derived from Indice de Precias de Consumb, Boletin Trimestral, Ocrubre-Diciambre 1987 and Octubre-Diciambre 1987. Seo Appendix for detrils.

${ }^{3}$ The input requirements of all inputt in the eqrieultural soctor, exeept imports, are divided by 0.9227 . The price of energy imports is multipliod by 0.5240 . See text for details.

4Weighted correlation coeficients with actual changes 1986/1985. The weights are the same as those in Footnote $\mathrm{L}$.

sweighted $\mathrm{R}^{2}$ in predicting actual changes $1986 / 1985$. The weights are the ante as that in Footnote 1. 
Table 4

Industrial Prices

(Percentage Change ${ }^{1}$ )

\begin{tabular}{|c|c|c|c|c|c|}
\hline & $\begin{array}{c}\text { Actual } \\
1986 / 1985^{2} \\
\end{array}$ & $\begin{array}{c}\text { Actual } \\
1987 / 1985 \\
\end{array}$ & $\begin{array}{c}\text { Model } \\
\text { Policy Only }\end{array}$ & $\begin{array}{c}\text { Model } \\
\text { Shocks Only }{ }^{3}\end{array}$ & $\begin{array}{c}\text { Model } \\
\text { Policy and } \\
\text { Shocls }\end{array}$ \\
\hline 1. Agriculture & -.3 & -6.9 & -6.0 & 8.0 & 1.6 \\
\hline 2. Energy & -17.9 & -27.2 & -7.5 & -32.8 & -37.8 \\
\hline 3. Basic Industry & -8.5 & -14.8 & -6.2 & -3.1 & -9.1 \\
\hline 4. Machinery & -3.1 & -3.5 & -6.5 & -.1 & -6.6 \\
\hline 5. Automobiles & -1.2 & .3 & -3.9 & .0 & -3.9 \\
\hline 6. Food Processing & -4.1 & -7.0 & -6.4 & 4.0 & -2.7 \\
\hline 7. Other Manufacturing & -4.3 & -4.5 & -5.7 & .5 & -5.1 \\
\hline 8. Construction & -.6 & -1.3 & -6.1 & .0 & -6.0 \\
\hline Change in Consumer Price Index & 8.4 & 13.5 & .0 & .0 & .0 \\
\hline Change in Industrial Price Index & 2.1 & 2.7 & -6.3 & -3.9 & -9.7 \\
\hline Weighted Correlation with $1986 / 1985^{4}$ & 1.000 & .985 & .794 & .840 & .960 \\
\hline Weighted Correlation with $1987 / 1985$ & .985 & 1.000 & .817 & .789 & .929 \\
\hline Prediction $R^{2}$ for $1986 / 1985^{5}$ & 1.000 & .622 & .627 & .146 & .046 \\
\hline Prediction $\mathrm{R}^{2}$ for $1987 / 1985$ & .848 & 1.000 & .547 & .575 & .789 \\
\hline
\end{tabular}

'Change in sectoral price index deflated by the conaumer price index.

${ }^{2}$ Actual data are derived from Boletin Trimestral de Coyuntura, Septiembre 1990. See Appendix for details.

${ }^{3}$ See Footnote 3 for Table 3 .

"WEighted (uncentered) correlation coefficient with actual changes 1986/1985. The weights used are value of total production ahares, (1) 0.1110 , (2) 0.1487 , (3) 0.1695 , (4) 0.1281 , (5) 0.0443 , (6) 0.1447 , (7) 0.1326 , and (8) 0.1211 .

Swighted $\mathrm{R}^{2}$ in predicting actual changes $1986 / 1985$. The weights are the same as those in Footote 1 . 
in macroeconomic variables reported in the second column of Table 6, where indirect tax revenues increase as a percentage of GDP and private consumption falls. We also see in Table 6 that tariff revenue falls in 1986 as a percentage of GDP.

Examining the second columns of Tables 4 and 5 and the third column of Table 6 , we see these same patterns in the changes that took place over 1985-87: a sharp fall in the price of producer goods relative to those of consumer goods accompanied by a rise in indirect tax revenues, a fall in consumption, and a fall in tariff revenues (as percentages of GDP). The results presented in the third columns of Tables 4 and 5 and the fifth column of Table 6 show that these patterns are captured by the model when it simulates the policy changes that took place in 1986.

Comparing the first and the second columns in Table 3 with the third column, we see that the model does poorly in tracking the changes that actually took place in two large sectors, food and transportation. The reasons for this should be readily apparent to observers of the Spanish economy. In 1986 food prices rose sharply because of a poor harvest, and gasoline prices fell sharply because of both an appreciation of the peseta against the dollar and a fall in the dollar price of petroleum. The final column of Table 3 reports the results of a simulation where we take these two exogenous shocks into account in the simplest possible ways: We reduce the ratio of output to inputs in the agricultural production sector by 7.73 percent. This number is the reduction in the ratio of an index of output to an index of intermediate inputs in agriculture from 1985 to 1986 , taken from the Anuario de Estadistica Agraria, 1987. We also reduce the price of energy by 47.60 percent. This number is the fall in the price index of energy imports from 1985 to 1986, taken from the Boletin Thimestral de Coyuntura, Septiembre 1990. (See the Appendix for details on the derivations of both of these numbers.)

In comparing the results of the model with the data we report two measures of goodness of prediction, each of which implicitly compares the match between the model prediction and the actual 
Table 5

Industrial Activity Levels

(Percentage Change ${ }^{1}$ )

\begin{tabular}{|c|c|c|c|c|c|}
\hline ( & $\begin{array}{c}\text { Actual } \\
1986 / 1985^{2}\end{array}$ & $\begin{array}{c}\text { Actual } \\
1987 / 1985\end{array}$ & $\begin{array}{l}\text { Model } \\
\text { Policy Only }\end{array}$ & $\begin{array}{c}\text { Model } \\
\text { Shocks Only }\end{array}$ & $\begin{array}{l}\text { Model } \\
\text { Policy and } \\
\text { Shocks }\end{array}$ \\
\hline 2. Energy & -2.7 & -7.2 & -2.3 & 3.1 & .4 \\
\hline 3. Basic Industry & -4.5 & -9.5 & 1.4 & -.6 & .8 \\
\hline 4. Machinery & 5.8 & 12.0 & 4.0 & -1.0 & 3.1 \\
\hline 5. Automobiles & 5.5 & 14.0 & 1.2 & 2.6 & 3.7 \\
\hline 6. Food Processing & -4.2 & -1.7 & -2.3 & -1.3 & -3.8 \\
\hline 7. Other Manufacturing & 1.9 & .0 & -2.4 & -.3 & -2.8 \\
\hline Industrial Output Index & 3.5 & 8.7 & -.2 & 2.0 & 1.8 \\
\hline Weighted Correlation with $1986 / 1985^{4}$ & 1.000 & .932 & .443 & -.193 & .389 \\
\hline Weighted Correlation with $1987 / 1985$ & .932 & 1.000 & .523 & -.311 & .416 \\
\hline Prediction $\mathrm{R}^{2}$ for $1986 / 1985^{5}$ & 1.000 & -.186 & .155 & -.225 & .104 \\
\hline Prediction $\mathrm{R}^{2}$ for $1987 / 1985$ & .691 & 1.000 & .237 & -.128 & .162 \\
\hline
\end{tabular}

${ }^{1}$ Change in sectoral industrial production index defated by industrial output index. The weight used are the value added ahares, (2) 0.1506 , (3) 0.2108 , (4) $0.2172,(5) 0.0511,(6) 0.1431$, and (7) 0.2271 .

${ }^{2.3}$ Seo Footnoted 2 and 3 for Table 3.

WWighted correlation coefficient with actual changes 1986/1985. The weights are the gane as thoue in Footnote 1.

Weighted $\mathrm{R}^{2}$ in predicting actual changes $1986 / 1985$. The weights are the same as those in Footnote 1 . 
change with the match between the prediction of no change and the actual change. The first is the weighted correlation coefficient:

$$
r=\sum_{i=1}^{n} \alpha_{i}^{2} y_{j} \hat{y}_{i} /\left(\sum_{i=1}^{n} \alpha_{i}^{2} y_{i}^{2} \sum_{i=1}^{n} \alpha_{i}^{2} \hat{y}_{i}^{2}\right)^{1 / 2} .
$$

Here $\alpha_{i}$ the weight measuring the relative size of sector $i ; y_{i}$ is the actual change in sector $i$; and $\varphi_{i}$ is the predicted change. A high correlation coefficient rewards predictions that have the right signs and relative magnitudes. It does not take into account the absolute magnitudes of changes. The second measure of goodness of prediction that we report is the weighted $\mathrm{R}^{2 \text {; }}$

$$
\mathrm{R}^{2}=1-\sum_{i=1}^{n} \alpha_{i}^{2}\left(y_{i}-\hat{y}_{j}\right)^{2} /\left(\sum_{i=1}^{a} \alpha_{i}^{2} y_{i}^{2}\right)
$$

A high $\mathrm{R}^{2}$ rewards small weighted mean squared error in prediction. Although this measure has the advantage of taking into account absolute magnitudes of changes, it has the disadvantages of being asymmetric in $y_{i}$ and $y_{i}$ and of heavily penalizing predictions that are correct in signs and relative magnitude but too large.

Once the exogenous shocks are incorporated into the model, it performs very well in accounting for the changes that actually took place in consumer prices. The correlation of the changes in the first column with those in the fourth, weighted in each case by 1980 consumption shares, is 0.936 . The prediction $\mathrm{R}^{2}$ is 0.657 ; in other words, by simulating the introduction of the VAT and the shocks to agricultural productivity and petroleum prices, the model is able to account for almost two thirds of the variation in relative prices that actually took place. It is important to notice that a substantial amount of variation did, in fact, take place. (See Figure 1.)

A comparison of the final three columns of Table 3 shows that accounting for both the policy changes and the exogenous shocks that occurred in 1986 is essential for the model to obtain these results. Incorporating the exogenous shocks separately produces changes in relative prices that have 
Figure 1

PRICES OF CONSUMER GOODS

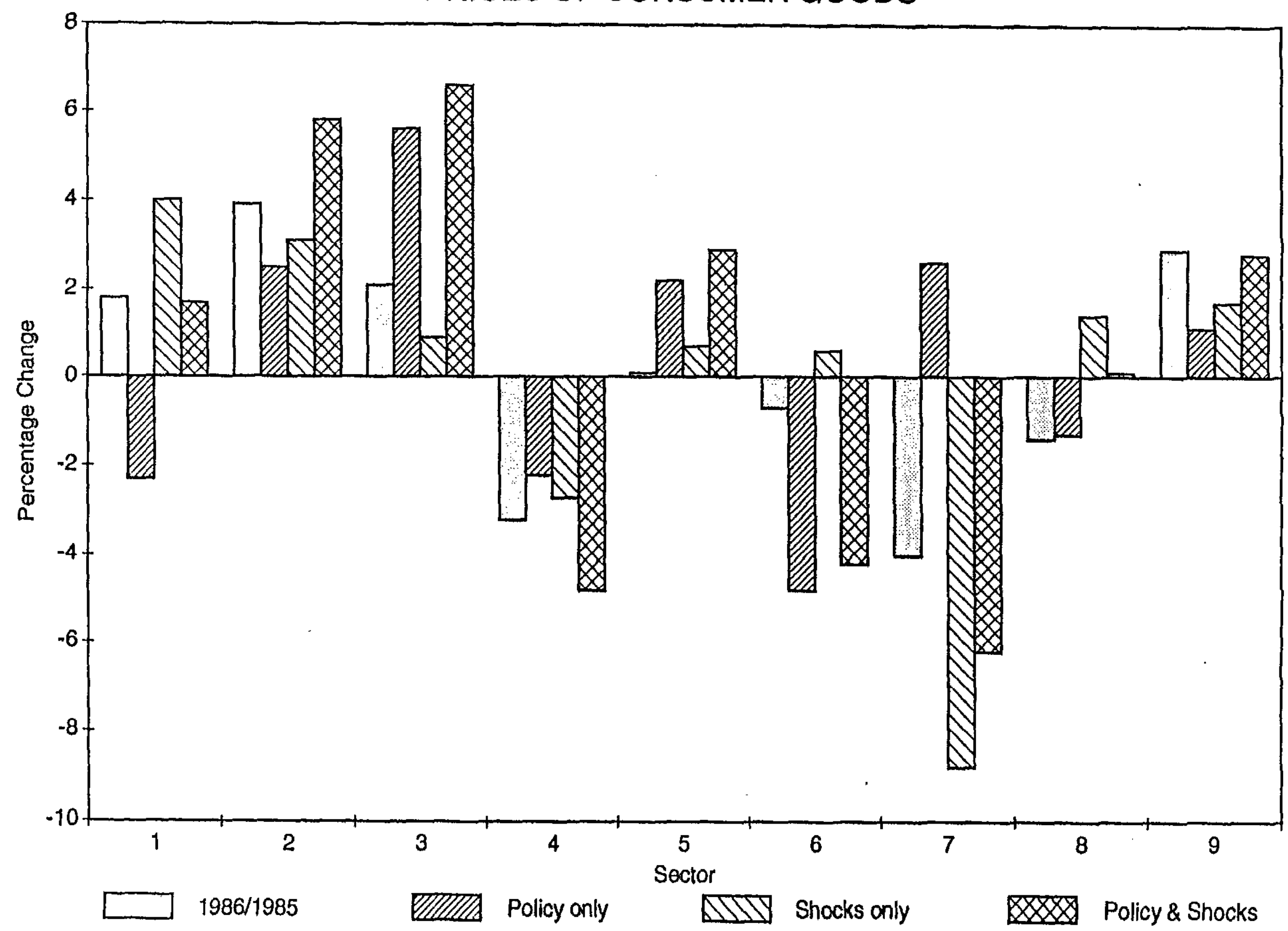


a lower weighted correlation coefficient with the changes that actually took place in $1986,0.872$, and a substantially lower prediction $\mathrm{R}^{2}, 0.226$.

In 1987 agricultural productivity recovered, although not to its 1985 level: The ratio of the index of output to the index of intermediate inputs taken from the Anuario de Estadistica Agraria, 1987 rose by 6.11 percent from 1986 to 1987 , although it was still 2.10 percent lower than it was in 1985. Petroleum prices fell even further: The price index of energy imports taken from the Boletin Trimestral de Coyuntura, Septiembre 1990 fell from 1985 to 1987 by 53.50 percent, a decrease of 11.26 percent from the 1986 level. Notice that the model without adjustments for the exogenous shocks performs better in predicting the changes that occurred from 1985-87 while the model adjusted for the 1986 shocks does worse. This seems to imply that most of the impact of the policy changes and the exogenous shocks were felt in the first year. We find in simulations not reported here that, if we adjust for the 1987 levels of agricultural productivity and petroleum prices, we do better in explaining the changes that took place between 1985 and 1987 than we do those that took place between 1985 and 1986. In other words, the impact of the policy changes and exogenous shocks on relative prices seems to be felt in the same year that the changes and shock occur, rather than with a lag. For this reason, we concentrate on the comparing the 1985-85 changes with the model results.

The performance of the model in tracking producer prices and activity levels, reported in Tables 4 and 5 is not as impressive as that for consumer prices. The model without adjustments underestimates the relative changes in producer prices that took place; the model with adjustments overestimates them. In both cases, however, the relative changes are in the right directions, causing the weighted correlation coefficients to be fairly high, 0.794 and 0.960 . (See Figure 2.) The model also does a fair, but not impressive, job in tracking changes in production, failing notably in the case of basic industry. (See Figure 3.) The decline in basic industry in Spain seems to be part of a secular trend that has occurred throughout the 1980 s but is not accounted for in the model. 
Figure 2

INDUSTRIAL PRICES

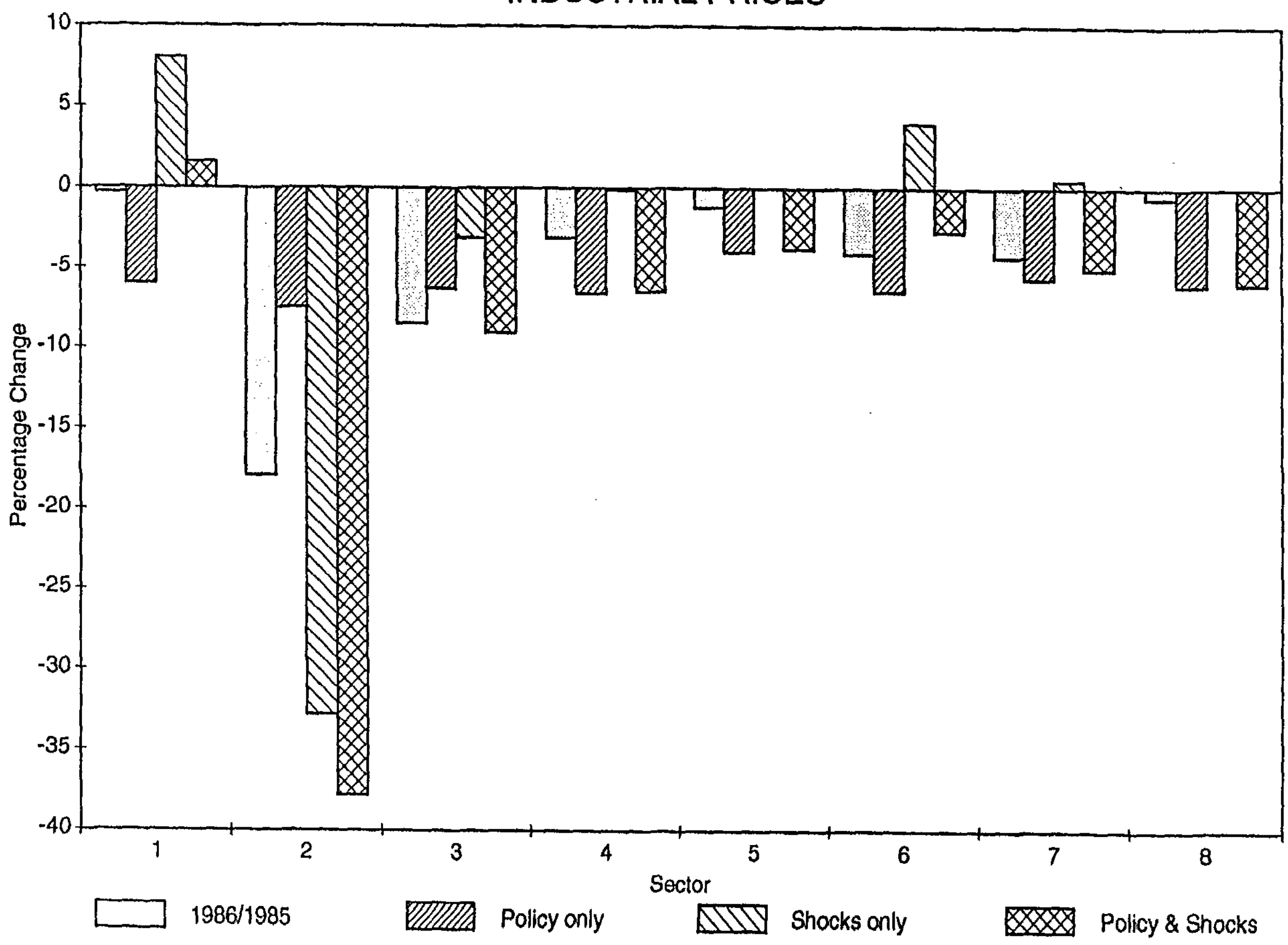


Figure 3

INDUSTRIAL ACTIVITY LEVELS

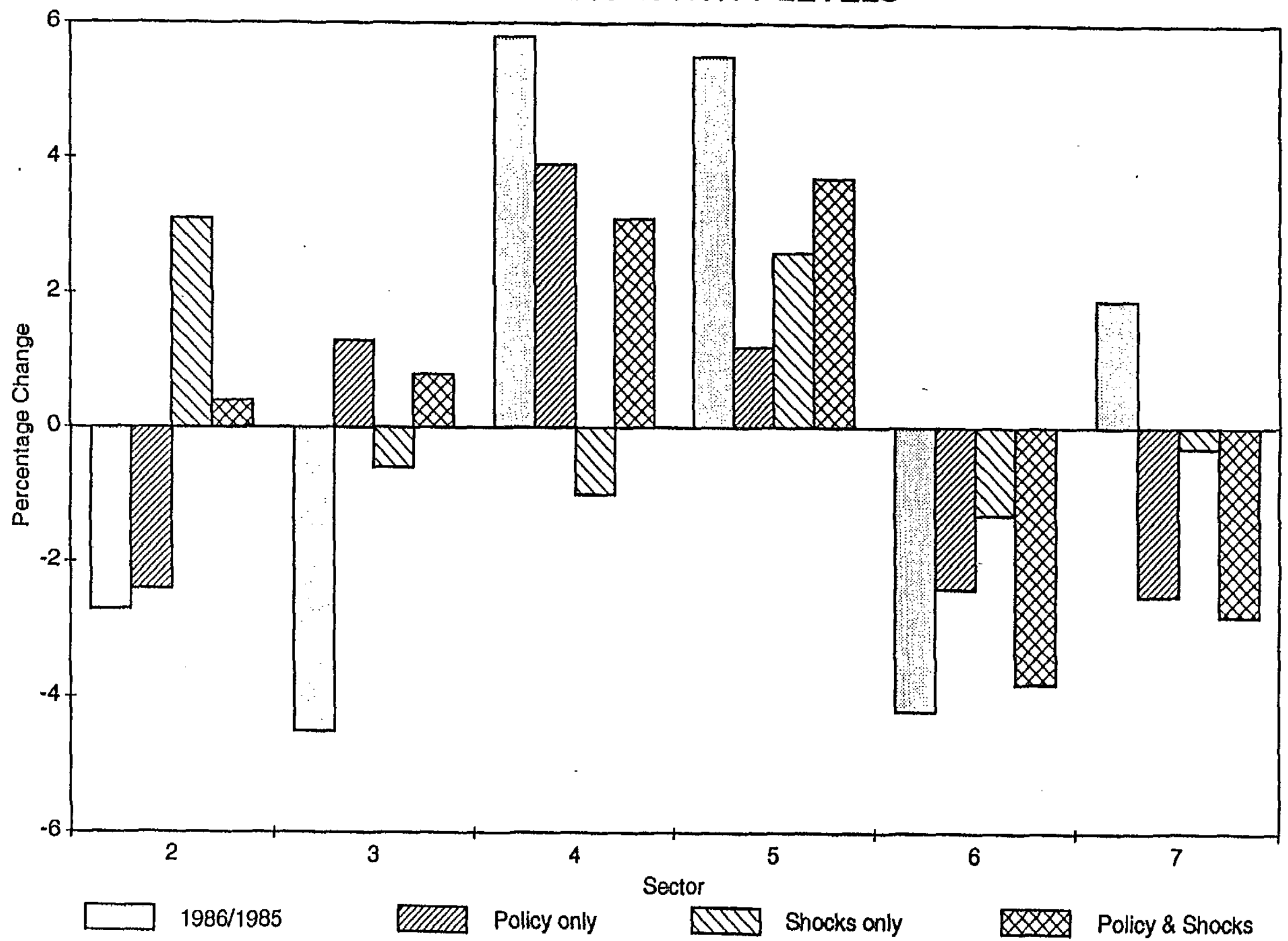


Notice that the 1985-87 changes in activity levels match the model results better than do the 1985-86 changes. It may be that, contrary to the intuition of proponents of sticky prices in economic models, prices adjust faster than quantities.

The performance of the model in tracking major macroeconomic variables, reported in Table 6, is, at first glance, spectacular. Much of the model's success in this direction, however, can be accounted for by simply remembering that the model predicted that the tax reform would result in a substantial increase in indirect taxes paid by consumers. It is worth pointing out that in 1985 this prediction of the model was controversial and was treated with considerable skepticism by a number of policymakers.

\section{Sensitivity to Labor Market Specifications}

In this section we study how robust are the results of our analysis of the 1986 indirect tax reform in Spain to the specification of the labor market. We take the activity levels of the government and foreign sectors as exogenous, and compare the output from the model in three scenarios: The two extreme cases, rigid wages $(\beta=\infty)$ and flexible wages $(\beta=0)$, and the intermediate situation $(\beta=1.5)$ found by Andres et al. (1988) to match Spanish data.

Tables 7-9 report the sensitivity to different choices of $\beta$ of the simulation results for the case with changes in policy only. We report the sensitivity analysis for this simulation, rather than one for the simulation with both policy changes and exogenous shocks, because Table 6 shows that the unemployment rates vary more in the simulation with policy changes only than they do in the one with policy changes and shocks. Consequently, the results of the simulation that incorporates policy changes only are more sensitive to different choices of $\beta$ than those are with policy changes and shocks.

Table 7 shows simulated commodity and factor prices after the tax reform. The numeraire here is the commodity price index. The most striking feature of the resuits is the lack of sensitivity 
Thble 6

Major Macroeconomic Variables

(Change From Benchmark)

\begin{tabular}{|c|c|c|c|c|c|c|c|}
\hline Unemployment & 21.94 & -.46 & -1.17 & 11.53 & 1.92 & -2.06 & -.08 \\
\hline $\begin{array}{l}\text { Wages and Salaries } \\
\text { Business Income } \\
\text { Net Indirect Taxes } \\
\text { Correlation with } 1986 / 1985^{4} \\
\text { Correlation with } 1987 / 1985 \\
\mathrm{R}^{2} \text { for } 1986 / 1985^{5} \\
\mathrm{R}^{2} \text { for } 1987 / 1985\end{array}$ & $\begin{array}{r}46.23 \\
46.79 \\
6.98\end{array}$ & $\begin{array}{r}-.53 \\
-1.27 \\
1.8 \\
1.000 \\
.999 \\
1.000 \\
.015\end{array}$ & $\begin{array}{r}-.43 \\
-1.21 \\
1.64 \\
.999 \\
1.000 \\
-.253 \\
1.000\end{array}$ & $\begin{array}{r}51.18 \\
44.26 \\
4.56\end{array}$ & $\begin{array}{r}-.87 \\
-1.64 \\
2.51 \\
.998 \\
.996 \\
.154 \\
.418\end{array}$ & $\begin{array}{r}-.03 \\
.45 \\
-.42 \\
-.939 \\
-.951 \\
.522 \\
.153\end{array}$ & $\begin{array}{r}-.90 \\
-1.25 \\
2.15 \\
.990 \\
.985 \\
.670 \\
.587\end{array}$ \\
\hline $\begin{array}{l}\text { Private Consumption } \\
\text { Private Investment } \\
\text { Government Consumption } \\
\text { Government Investment } \\
\text { Exports } \\
\text { Imports } \\
\text { Correlation with } 1986 / 1985 \\
\text { Correlation with } 1987 / 1985 \\
\mathbf{R}^{2} \text { for } 1986 / 1985 \\
\mathbf{R}^{2} \text { for } 1987 / 1985\end{array}$ & $\begin{array}{r}69.31 \\
15.04 \\
14.01 \\
3.75 \\
18.40 \\
20.51\end{array}$ & $\begin{array}{r}-.81 \\
1.09 \\
-.02 \\
-.06 \\
-3.40 \\
-3.20 \\
1.000 \\
.452 \\
1.000 \\
.991\end{array}$ & $\begin{array}{r}-1.27 \\
3.11 \\
.39 \\
-.09 \\
-3.93 \\
-1.79 \\
.452 \\
1.000 \\
.992 \\
1.000\end{array}$ & $\begin{array}{r}69.00 \\
21.46 \\
12.68 \\
1.87 \\
12.50 \\
17.51\end{array}$ & $\begin{array}{r}-1.24 \\
1.81 \\
-.06 \\
-.06 \\
-.42 \\
.03 \\
.397 \\
.716 \\
.854 \\
.738\end{array}$ & $\begin{array}{r}-.51 \\
-.58 \\
-.38 \\
-.07 \\
-.69 \\
-2.23 \\
.766 \\
.396 \\
-.585 \\
-.650\end{array}$ & $\begin{array}{r}-1.78 \\
1.32 \\
-.44 \\
-.13 \\
-1.07 \\
-2.10 \\
.834 \\
.791 \\
.950 \\
.889\end{array}$ \\
\hline $\begin{array}{l}\text { Indirect Taxes and Subsidies } \\
\text { Tariffs } \\
\text { Social Security Payments } \\
\text { Net Direct Taxes/Transfers } \\
\text { Government Capital Income } \\
\text { Government Spending } \\
\text { Government Deficit } \\
\text { Correlation with } 1986 / 1985 \\
\text { Correlation with } 1987 / 1985 \\
\mathrm{R}^{2} \text { for } 1986 / 1985 \\
\mathrm{R}^{2} \text { for } 1987 / 1985\end{array}$ & $\begin{array}{r}4.99 \\
1.99 \\
11.35 \\
-9.36 \\
11.77 \\
17.75 \\
7.02\end{array}$ & $\begin{array}{r}2.38 \\
-.58 \\
.04 \\
-.84 \\
-.13 \\
-.08 \\
-.95 \\
1.000 \\
.463 \\
1.000 \\
.204 \\
\end{array}$ & $\begin{array}{r}2.06 \\
-.42 \\
-.12 \\
2.65 \\
-.43 \\
.30 \\
-3.44 \\
.463 \\
1.000 \\
-1.459 \\
1.000 \\
\end{array}$ & $\begin{array}{r}2.78 \\
1.78 \\
11.63 \\
-5.77 \\
1.51 \\
14.55 \\
2.62\end{array}$ & $\begin{array}{r}3.32 \\
-.81 \\
-.19 \\
-.66 \\
-.06 \\
-.12 \\
-1.72 \\
.984 \\
.602 \\
.788 \\
.322 \\
\end{array}$ & $\begin{array}{r}-.38 \\
-.03 \\
-.03 \\
.92 \\
.01 \\
-.45 \\
-.94 \\
-.184 \\
.681 \\
-.464 \\
.316 \\
\end{array}$ & $\begin{array}{r}2.98 \\
-.83 \\
-.22 \\
.25 \\
-.04 \\
-.56 \\
-2.70 \\
.868 \\
.808 \\
.348 \\
.651 \\
\end{array}$ \\
\hline
\end{tabular}

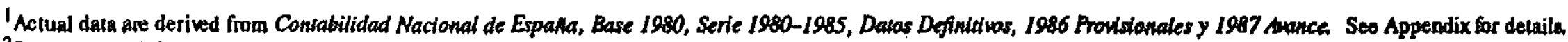
${ }^{2}$ See Footnote 3 for Table 3.

${ }^{3}$ All variables except the unemployment rales are expreseed as percentagen of GDP.

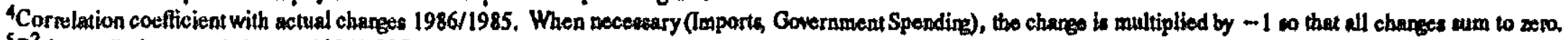

$5^{2}$ in predicting actual cheres $1986 / 1985$. 
Tabie 7

Market Prices

(Percentage Change ${ }^{1}$ )

\begin{tabular}{lllll}
\hline & & & & Rigid Waged Unemployment \\
& & $\beta=0^{2}$ & $\beta=1.5$ & $\beta=\infty$ \\
\hline Production & & & \\
1. Agriculture & & -5.80 & -6.00 & -6.22 \\
2. Energy & -7.59 & -7.51 & -7.41 \\
3. Basic Industry & -6.36 & -6.22 & -6.07 \\
4. Machinery & -6.82 & -6.53 & -6.18 \\
5. Automobile Industry & -4.26 & -3.90 & -3.47 \\
6. Food Products & -6.37 & -6.41 & -6.46 \\
7. Other Manufacturing & -5.92 & -5.68 & -5.40 \\
8. Construction & -6.45 & -6.08 & -5.64 \\
9. Commerce & -5.83 & -5.94 & -6.08 \\
10. Transportation & -6.21 & -6.09 & -5.94 \\
11. Services & -6.20 & -6.20 & -6.20 \\
12. Government Services & -4.34 & -3.40 & -2.34
\end{tabular}

\section{Consumption Demand}

1. Food and Nonalcoholic Beverages

-2.16
2.60
5.52
-2.28
2.09
-4.84
2.57
-1.41
1.16

$-2.25$

2.53

$-2.35$

2. Tobacco and Alcoholic Beverages

5.63

2.46

3. Clothing

4. Housing

$-2.25$

5.77

5. Household Articles

6. Medical Services

7. Transportation

8. Recreational Services

9. Other Services

\section{Nonconsumption Demand}

1. Investment

2. Commerce with EC

3. Commerce with ROW

$$
\begin{aligned}
& -6.33 \\
& -6.00
\end{aligned}
$$$$
-6.37
$$

$-6.05$

$-5.86$

$-6.23$
$-5.71$

$-5.69$

$-6.07$

\section{Factors of Production}

1. Unskilled Labor

2. Skilled Labor

3. Capital

$$
\begin{array}{r}
-3.58 \\
-3.91 \\
-5.34
\end{array}
$$

$-.85$

$-.34$

$-7.56$

'The numeraire is the consumer price index. The weights on the prices of consumption goods are the ame al those in Footnote 1 for Table 3 .

${ }^{2}$ Here $\omega_{i}=\left[\left(1-u_{i}\right) /\left(1-\bar{u}_{i}\right)\right]^{1 / \beta}$ where $\omega_{i}$ is a real wage index, $u_{i}$ is the unemployment rate, and $\vec{u}_{i}$ is the benebmark unemployment rate. The govemment deficit and the trade deficits with the EC and the rest of the world are endogenous. Only policy changes are incorporated. 
of production and consumption prices to the value of $\beta$. In contrast, factor prices appear quite sensitive to the speciffcation of the labor market. Notice that the greater the rigidity of real wages, the higher is the price of labor relative to capital. Since relative prices determine the optimal capital/labor ratios chosen by producers, we can conclude that the tax reform is not neutral in terms of income distribution. This illustrates the importance of using a general equilibrium analysis to assess the importance of economy-wide tax reforms. The changes in factor prices result from a drop in demand brought about by an increase in consumption prices; since capital is always fully employed, the fall in demand and activity levels increases the price of labor relative to capital. Observe that the less sensitive are real wages to unemployment, the greater are these increases.

Since factor prices are one of the basic components of production costs, their small influence on the prices of goods can be explained by factor substitution offsetting changing factor costs. This is a subject worth investigating: Perhaps a cause is that the assumed elasticities of substitution among primary factors are not adequate to pick up the feedback of demand on prices via labor markets.

In Table 8, we present the effects of the fiscal reform on activity levels and income distribution. Notice that most of the sectors producing consumption goods and services experience fairly consistent drops in activity levels in all labor market scenarios. In contrast, the effects on sectors producing capital goods clearly depend on the degree of sensitivity of unemployment to changes in real wages. The changes in activity levels in the capital goods sectors can be largely accounted for by the changes in investment. We observe that, although real income indices drop in all scenarios, the fall increases with the rigidity of real wages. This is so because the increase in unemployment reduces consumers' income.

Major macroeconomic variables are reported in Table 9. We observe that unemployment rates increase by $2-4$ percent in the second two scenarios. Net indirect taxes, which include indirect taxes, subsidies, and tariffs, increase by more than 2 percent of GDP in all cases. Net direct taxes 
Table 9

Major Macroeconomic Variables

(Change from Benchmark)

\begin{tabular}{|c|c|c|c|c|}
\hline & & $\begin{array}{c}\text { Fixed } \\
\text { Unemployment }\end{array}$ & & $\begin{array}{l}\text { Rigid } \\
\text { Wages }\end{array}$ \\
\hline Variable & $\begin{array}{c}1980 \\
\text { Benchmark }\end{array}$ & $\beta=0^{l}$ & $\beta=1.5$ & $\beta=\infty$ \\
\hline Unemployment & 11.53 & .00 & 1.92 & 4.13 \\
\hline Unskilled & 11.53 &.$\infty 0$ & 1.93 & 4.17 \\
\hline Skilled & 11.53 & .00 & 1.78 & 2.79 \\
\hline Wages and Salaries ${ }^{2}$ & 51.18 & -.98 & -.87 & -.82 \\
\hline Returns to Capital & 44.26 & -1.59 & -1.64 & -1.72 \\
\hline Net Indirect Taxes & 4.56 & 2.47 & 2.51 & 2.54 \\
\hline Private Consumption & 69.00 & -1.65 & -1.24 & -.72 \\
\hline Private Investment & 21.46 & 2.69 & 1.81 & .76 \\
\hline Government Consumption & 12.68 & -.31 & -.06 & .23 \\
\hline Government Investment & 1.87 & -.09 & -.06 & -.04 \\
\hline Exports & 12.50 & -.55 & -.42 & -.26 \\
\hline Imports & 17.51 & .09 & .03 & -.03 \\
\hline Indirect Taxes and Subsidies & 2.78 & 3.29 & 3.32 & 3.36 \\
\hline Tariffs & 1.78 & -.81 & -.81 & -.82 \\
\hline Social Security Payments by Employers & 11.63 & -.20 & -.19 & -.18 \\
\hline Net Direct Taxes and Transfers & -5.77 & -.14 & -.66 & -1.29 \\
\hline Government Capital Income & 1.51 & -.05 & -.06 & -.06 \\
\hline Government Spending & 14.55 & -.40 & -.12 & -.08 \\
\hline Government Deficit & 2.62 & -2.49 & -1.72 & -1.60 \\
\hline
\end{tabular}

${ }^{1}$ See Footnote 2 for Table 7 .

${ }^{2}$ All variables except the unemployment rates are expressed 2s percentages of GDP. 
as a percentage of GDP falls, however, as the sensitivity parameter $\beta$ goes up; this fall is due to a decline in the income tax base resulting from higher unemployment and to higher unemployment payments to unemployed. Not surprisingly, the public deficit as a proportion of GDP goes down, although the improvement decreases with $\beta$. Since the level of government activity is exogenously fixed, the ratio of the government deficit to GDP changes by approximately the same amount as does total tax collection.

Private consumption as a proportion of GDP falls relative to its benchmark value; in this case, though, the fall is smaller the higher the rigidity of wages. Investment increases shaply with respect to its benchmark value, the increase being smaller the greater the rigidity of wages. It is the fall in the prices of investment goods that explains the increase in savings and investment relative to its benchmark value, and the increase in unemployment with $\beta$ is what accounts for the fall in investment as $\beta$ rises.

The results presented above are pleasing in two respects. First, they illustrate the relative insensitivity of our analysis on the 1986 fiscal reform to the specification of the labor markets, which is a weak point of the model from a theoretical perspective. Second, they can all be explained in intuitive terms. This is a major advantage of the simple structure of the model.

\section{Sensitivity to Macroeconomic Closure Rules}

In the previous two sections, we have discussed the results of simulations in which all deffits are endogenous. In this section, we investigate the sensitivity of the simulation results to macroeconomic closure rules. Since the government deficit and the foreign sectors deficit can be either endogenous or exogenous, there are potentially eight cases to examine. Since our results are relatively insensitive to the closure rule for the trade deficit, we report only four cases, those where either both trade deficits are endogenous or both are exogenous. The results for all 8 cases as well as scenarios in which there is uniform 30 percent evasion of the VAT are reported by Kehoe et al. 
(1989). The column headings in Table 10 identify the scenarios reported here. For instance, XE means eXogenous government deficit and Endogenous trade deficits with the EEC and with the ROW. In each of the simulations $\beta=1.5$ in the specification of the labor market.

Tables 10-12 report the sensitivity to different macroeconomic closure rules of the simulation results for the case with both policy changes and exogenous shocks. Table 6 shows that the government deficit and the trade deficits vary much more in this simulation than they do in the simulation with policy changes only. Consequently, the results of the simulation that incorporates both policy changes and exogenous shocks are more sensitive to fixing these deficits exogenously than those of the simulation that incorporates policy changes only.

In fact, however, Table 10 shows that relative prices are fairly insensitive to the closure rule chosen. Table 10 also shows that the increase in the price of labor relative to that of capital is larger in the final two cases, where the government deficit is exogenous and government demand varies with tax revenues. The increase in government tax revenues due to the fiscal reform results in an increase in government activity, which is relatively labor intensive.

Activity levels of production sectors are somewhat more sensitive to the closure rule, particularly to whether the government deficit is endogenous or exogenous. Table 11 indicates that keeping constant the government deficit reduces public and total savings, and hence eliminates the beneficial effects of the tax reform on the activity levels of the investment goods sector. It also indicates that making the level of exports endogenous has a distinctive effect on the automobile sector (contrast columns EX and EE).

Consumers' real income is sensitive only to the government closure rule. As we see in Table 11, keeping the government deficit constant tends to make poor consumers better off and richer consumers worse off; it is the greater increase in the price of labor to that of capital in this case that 
Table 10

Market Prices

(Percentage Change')

\begin{tabular}{lrrrr}
\hline Sector & EE & EX & XE & $X X$ \\
\hline Production & & & & \\
1. Agriculture & 1.55 & 1.54 & 1.39 & 1.37 \\
2. Energy & -37.84 & -37.84 & -37.80 & -37.80 \\
3. Basic Industry & -9.06 & -9.05 & -8.96 & -8.94 \\
4. Machinery & -6.56 & -6.55 & -6.35 & -6.32 \\
5. Automobile Industry & -3.88 & -3.85 & -3.61 & -3.56 \\
6. Food Products & -2.66 & -2.66 & -2.71 & -2.71 \\
7. Other Manufacturing & -5.13 & -5.11 & -4.95 & -4.93 \\
8. Construction & -6.04 & -6.02 & -5.77 & -5.73 \\
9. Commerce & -4.21 & -4.21 & -4.29 & -4.31 \\
10. Transportation & -7.69 & -7.69 & -7.60 & -7.59 \\
11. Services & -3.98 & -3.98 & -3.96 & -3.96 \\
12. Government Services & -2.48 & -2.43 & -1.61 & -1.52
\end{tabular}

\section{Consumption Demand}

1. Food and Nonalcoholic Beverages

2. Tobacco and Alcoholic Beverages

3. Clothing

4. Housing

5. Household Articles

6. Medical Services

7. Transportation

8. Recreational Services

9. Other Services

\subsection{5}

5.77

6.65

$-4.83$

2.89

$-4.20$

$-6.20$

.11

2.82
1.65

5.76

6.66

$-4.83$

2.90

$-4.20$

$-6.20$

.12

2.82
1.58

5.71

6.73

$-4.79$

2.97

$-4.17$

$-6.15$

.17

2.77
1.57

5.70

6.75

$-4.79$

2.98

$-4.17$

$-6.15$

.17

2.76

\section{Nonconsumption Demand}

1. Investment

2. Commerce with EC

$-5.77$

$-5.76$

$-5.56$

$-5.53$

$-6.76$

$-6.75$

$-6.66$

$-6.64$

3. Commerce with ROW

$-8.24$

$-8.23$

$-8.14$

$-8.13$

\section{Factors of Production}

1. Unskilled Labor

$\begin{array}{ll}-.67 & -.59\end{array}$

.24

$-.59 \quad-.57$

4.20

.36

2. Skilled Labor

$-1.66$

$-1.72$

$-2.45$

4.35

3. Capital

$-1.66$

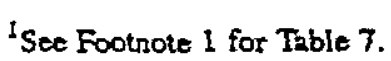

${ }^{2}$ HFere EX, for example, means Endogenous government deficit and eXogenous deficits with the EC and the rent of the world. B is equal to 1.5. Both policy changes and exogenous shocks are incorporated. 
Table 11

Activity Levels and Consumers' Real Income Indices (Percentage Changes)

\begin{tabular}{lrrrr}
\hline & $\mathrm{EE}^{1}$ & $\mathrm{EX}$ & $\mathrm{XE}$ & \multicolumn{1}{c}{$\mathrm{XX}$} \\
\hline Production & \\
& & & & \\
1. Agriculture & -1.55 & -1.68 & -1.84 & -2.14 \\
2. Energy & 2.30 & 1.52 & 1.82 & .84 \\
3. Basic Industry & 2.72 & 1.49 & -.65 & -1.56 \\
4. Machinery & 5.08 & 5.52 & .76 & 1.30 \\
5. Automobile Industry & 5.62 & 8.51 & 2.09 & 4.70 \\
6. Food Products & -1.93 & -2.68 & -1.56 & -2.46 \\
7. Other Manufacturing & -.92 & -1.44 & -2.17 & -2.93 \\
8. Construction & 9.79 & 12.54 & 1.39 & 4.94 \\
9. Commerce & -1.94 & -1.78 & -1.88 & -1.74 \\
10. Transportation & .65 & -1.08 & .64 & -1.52 \\
11. Services & 1.77 & 1.83 & 1.26 & 1.35 \\
12. Government Services & .00 & .00 & 20.75 & 21.25
\end{tabular}

Nonconsumption Demand ${ }^{2}$

1. Investment

2. Commerce with $\mathrm{EC}$

3. Commerce with ROW
12.85

.00

.00
16.54

10.29

$-24.17$
1.11

.00

.00
5.85

7.59

$-26.57$

\section{Consumers $^{3}$}

1. Young, low income

2. Young, high income

3. Adult, skilled, low

$-.68$

.27

$-.44$

.56

$-.56$

5. Adult, unskilled, low

.48

$-.36$

7. Old, low income

.62

.99

1.17

.71

.73

.49

.62

$.40 \quad .38$

$\begin{array}{ll}4.85 & 4.98\end{array}$

$-.43 \quad-.54$

$-.37 \quad-.37$

${ }^{1}$ See Footnote 2 for Table 10.

${ }^{2.3}$ See Footnotes 2 and 3 for Table 8. 
explains this result. Indeed, poor consumers income comes mainly from labor, whereas capital income plays a larger role for richer consumers.

Turning to macroeconomic indicators in Table 12, we notice the positive effects of the changes that occurred in 1986 on employment are magniffed when government expenditures are allowed to increase with revenues. We would therefore expect that the increase in government expenditures that actually occurred in 1986 in Spain (around 6 percent in real terms) helped to increase employment. Notice in Table 6 that unemployment did, in fact, fall in 1986 and 1987.

Tax revenues show little sensitivity to the closure rules, although we detect a slight increase in net direct taxes when the government deficit is fixed. This is due to the fall in unemployment, which increases private income and reduces unemployment compensation payments. Private consurnption does not seem to be very sensitive to the closure rule. Allowing government spending to increase with tax revenues, however, reduces the ratio of private investment to GDP by roughly 3 percent. This result suggests that the growth of public expenditure in real terms in 1986 may have softened to some extent the investment boom that the tax reform would have prompted.

\section{Discussion}

One chalienge is to use the shortcomings of this model to develop a new version of the model more suitable for prediction. One obvious direction to take is to incorporate secular trends and to account for more exogenous shocks. What is surprising in the previous section is how well the model does without doing this. Another is to come up with better elasticities in consumer demand functions and production functions. We have not even addressed the issue of sensitivity to these parameters, which are now all either one or zero. (See Bernheim, Sholz, and Shoven 1991 and Harrison and Vinod 1992 for examples of work in this direction.) Another possibility is to use the changes that actually take place to calibrate certain parameters. Kehoe and Serra-Puche (1991), for example, use the change in imports that took place in Mexico between 1980 and 1983, in response to a sharp fail 
Table 12

Major Macroeconomic Variables (Change From Benchmark)

\begin{tabular}{|c|c|c|c|c|c|}
\hline Variable & $\begin{array}{c}\text { Benchmark } \\
1980 \\
\end{array}$ & $E^{\prime}$ & EX & $\mathrm{XE}$ & $x x$ \\
\hline Unemployment & 11.53 & -.08 & -.17 & -1.48 & -1.54 \\
\hline Unskilled & 11.53 & -.08 & -.17 & -1.25 & -1.41 \\
\hline Skifled & 11.53 & -.10 & -.12 & -6.55 & -6.74 \\
\hline Wages and Salaries ${ }^{2}$ & 51.18 & -.90 & -.85 & -.10 & -.01 \\
\hline Returns to Capital & 44.26 & -1.25 & -1.31 & -1.98 & -2.08 \\
\hline Net Indirect Taxes & 4.56 & 2.15 & 2.16 & 2.08 & 2.09 \\
\hline Private Consumption & 69.00 & -1.78 & -1.81 & -2.07 & -2.12 \\
\hline Private Investment & 21.46 & 1.32 & 2.10 & -1.76 & -.77 \\
\hline Government Consumption & 12.68 & -.44 & -.44 & 2.27 & 2.32 \\
\hline Government Investment & 1.87 & -.13 & -.13 & .24 & .25 \\
\hline Exports & 12.50 & -1.07 & -1.89 & -1.17 & -2.27 \\
\hline Imports & 17.51 & -2.10 & -2.17 & -2.49 & -2.59 \\
\hline Indirect Taxes and Subsidies & 2.78 & 2.98 & 2.99 & 2.94 & 2.95 \\
\hline Tariffs & 1.78 & -.83 & -.83 & -.86 & -.86 \\
\hline Social Security Payments by Employers & 11.63 & -.22 & -.21 & -.02 & .01 \\
\hline Net Direct Taxes and Transfers & -5.77 & .25 & .28 & .59 & .63 \\
\hline Government Capital Income & 1.51 & -.04 & -.05 & -.07 & -.07 \\
\hline Government Spending & 14.55 & -.56 & -.57 & 2.50 & 2.57 \\
\hline Government Deficit & 2.62 & -2.70 & -2.75 & -.08 & -.08 \\
\hline
\end{tabular}

${ }^{2}$ See Footnote 2 for Table 10.

${ }^{2}$ All variables except the unemployment rates are expressed 28 a percentage of GDP. 
in the terms of trade, to calibrate the Armington elasticity of substitution between imports and domestic production in a similar model of the Mexican economy. The results in the previous section suggest many other possible improvements in the model: That the fall in the price of petroleum was not passed on to purchasers of energy products to the extent our model predicts, for example, might indicate that our assumption of perfect competition in this market should be modified.

Another obvious challenge is to figure out what types of policy changes or exogenous shocks this model is capable of analyzing and what types it is not. It probably comes as a surprise to some readers that the model does so well even though it takes intertemporal factors into account in very simplistic ways, if at all. Certainly, the authors would not expect the model to perform as well in evaluating the impact of, say, a tax reform that significantly changes the tax rate on capital income. An interesting project would involve using a fully speciffed dynamic applied general equilibrium model, such as that of Auerbach and Kotlikoff (1987), Goulder and Summers (1989), or Jorgenson and Yun (1990), to analyze a policy change such as that analyzed here. The results of the dynamic model would then be compared with the results of the static model and with the actual data.

Another issue that we should mention is that of data availability. This is a constant limitation in this line of research. The reader will have noticed that throughout the analysis we have had to use a model calibrated to 1980 data to analyze changes that took place six years later. Furthermore, it is only in 1990 that we have sufficient data to evaluate the performance of the model. In fact, the version of the model constructed in 1985 did not even utilize a complete dataset for 1980 (see Kehoe et al. $1985 \mathrm{~b}$ for the dataset that was used at the time). The later improvement in the dataset accounts for the differences in simulation results between, for example, Kehoe et al. (1985a) and Kehoe et al. (1989). The basic predictions concerning consumer prices and major macroeconomic variables were present, however, even in earliest version of the model. (See the Appendix for details.) Obviously, the model improves with more and better (for example, more recent) data. How much data do we 
need, and how good does it have to be, to have confidence in our simulation results? This paper brings us one step further to answering these questions. More work remains to be done. 


\section{Appendix}

\section{A. Derivation of Actual Changes 1985-87}

Data on consumer prices: Indices for Sectors 3-9 are taken from Indice de Precios de Consumo, Boletin Trimestral, Octubre-Diciembre 1986, pp. 8-9 and Octubre-Diciembre 1987, pp. 8-9. The category food in the IPC is an aggregate of a large number of subcategories that include tobacco and alcoholic beverages. We construct our own indices for food and nonalcoholic beverages, Sector 1 , and for tobacco and alcoholic beverages, Sector 2 , using the relations

$$
\begin{aligned}
& p_{\text {tood }}=w_{1} p_{1}^{*}+w_{2} p_{2}^{*} \\
& p_{2}^{*}=w_{\text {alcohol }} P_{\text {alcobol }}+w_{\text {tobacco }} P_{\text {tobacco }}
\end{aligned}
$$

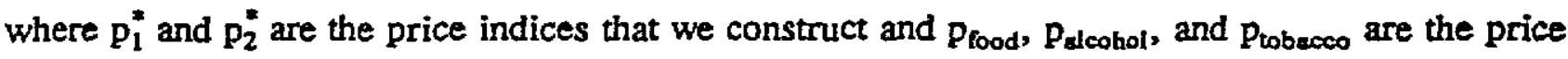
indices in the IPC. The weights $w_{1}$ and $w_{2}$ are 0.8753 and 0.1247 ; they are taken from Kehoe et al (1988b). The weights $w_{\text {slcobol }}$ and $w_{\text {tobaceo }}$ are 0.4480 and 0.5520 ; they are taken from the Bolettn Thimestral.

Dividing the price indices in December 1986 by those in December 1985, we produce a vector of $1986 / 1985$ price indices. Summing these using the consumer expenditure weights reported in Footnote 1 of Table 3, we produce an aggregate price index. We compute the changes reported in Table 3 by dividing each of the numbers in our vector of price indices by this aggregate index and subtracting one.

Data on industrial prices: Price indices are taken from Boletin Trimestral de Coyuntura, Septiembre 1990. The index for agriculture comes from p. 85, Table IV.1, series 175; that for energy is from p. 86, IV.2, 99; that for basic industry is from p. 86, IV.2, 100; that for construction is from p. 87, IV.3, 120. The machinery category in the Boletin is an aggregate of our machinery and automobiles categories. We disaggregate the machinery index from p. 86, IV.2, 101 using the automobile index from p. 108, VI.4, 111. The weights are proportional to the value of total 
production weights reported in Footnote 4 of Table 4 . Similarly, the other manufacturing category in the Bolettn is an aggregate of our food processing and other manufacturing categories. We disaggregate the other manufacturing index from p. 86, IV.2, 102 using the food processing index from p. 109, VI.5, 112. The changes reported in Table 4 are constructed using the same method as that described above for consumer prices.

Data on industrial activity levels: Production indices are taken from the Boletn Trimestral de Coyuntura, Septiembre 1990. The procedure followed is analogous to that described above for consumer prices. The index for energy is taken from p. 52, Table I.6, series 77; that for basic industry is taken from p. 53, $1.7,78$; that for machinery is taken from p. $54,1.8,82$; that for automobiles is taken from p. 108, VI.4, 81; that for food processing is taken from p. 109, VI.5, 56; and that for other manufacturing is taken from p. $55,1.9,83$. The weights used to disaggregate the indices for machinery and automobiles and the indices for food processing and other manufacturing are proportional to the value added weights reported in Footrote 1 of Table 5.

Data on macroeconomic variables: A set of simpliffed national income accounts was constructed for each of the years 1980,1985, 1986, and 1987 using the data found in various editions of Contabilidad Nacional de Espana. See Kehoe et al. (1988b) for the accounts for 1980. Comparing the accounts for 1980 reported in Table 6 and those of the Contabilidad Nacional de Espana for 1980, it is easy to reconstruct the aggregation procedure used and to apply it to 1985 , 1986 , and 1987.

Data on agricultural productivity and prices of energy imports: The changes in the prices of energy imports are taken from Boletin Trimestral de Coyuntura. Septiembre 1990, p. 90, IV.6, 288. The ratios of the index of final production to the index of intermediate inputs is obtained by dividing index C by index D from p. 633 of Anuario de Estadistica Agraria. 1987. 


\section{B. Data Sources}

Anuarto de Estadistica Agraria, 1987. Madrid: Ministerior de Agricultura, 1990.

Boletin Trimestral de Coyuntura. Septiembre 1990. Madrid: Instituto Nacional de Estadística, 1990. Contabilidad Nacional de Espana, Base 1980, Cuentas Nacionales y Tabla Input-Output. Madrid: Instituto Nacional de Estadística, 1986.

Contabilidad Nacional de Espana, Base 1980, Serie 1980-84 Definitivos, 1985 Provisional y 1986 Avance Madrid: Instituto Nacional de Estadística, 1987.

Contabilidad Nacional de Espana, Base 1980, Serie 1985 Definitivos, 1986 Provistonal y 1987 Avance Madrid: Instituto Nacional de Estadística, 1988.

Encuesta de Presupuestos Familiares, 1980-81. Madrid: Instituto Nacional de Estadistica, 1983. Indice de Preclos de Consumo, Boletin Ttimestral, Octubre-Diciembre 1986. Madrid: Instituto Nacional de Estadfstica, 1987.

Indice de Precios de Consumo, Boletin Trimestral, Octubre-Diciembre 1987. Madrid: Instituto Nacional de Estadística, 1988.

\section{Results of Earlier Versions of the Model}

Kehoe et al (1985a, 1986a, 1986b, 1988a) present results that differ from those in this paper and those presented by Kehoe et al. (1989). The reason is that the original version of the model relied on an incomplete dataset for 1980 , which is presented by Kehoe et al (1985b). The primary differences between this dataset and that presented by Kehoe et al. (1988b) is that the former utilized a 1975 input-output matrix updated to 1980 using the well known RAS method while the latter utilized a 1980 input-output output matrix. Neither input-output matrix included a conversion matrix to convert the classification of producer goods into the classification of consumer goods. For the original dataset, Kehoe et al. (1985b) constructed such a matrix based on incomplete information from various sectors obtained from the Instituto Nacional de Estadistica. For the final dataset, Kehoe et 
al. (1988b) obtained such a matrix constructed especially for this project by the Instinto Nacional de Estadistica.

Below we present the results obtained using the earlier version of the model. There are a few (very minor) differences among the various published versions of these earlier results. These can be explained by (1) small differences in the tariff rates, which changed as better information was obtained on the actual tariff rates imposed in 1986, (2) a programming error in computing government. demand in the earliest version of the model, and (3) differences in the specification of the macro closure rules or of the labor market clearing conditions. These differences are not significant in any sense. In fact, they are difficult to detect given the level of accuracy used here in reporting the results. These results are for a model with flexible wages $(\theta=0)$ and endogenous government and trade deficits. The weighted correlations reported use the same weights as those reported in the text. 
Consumer Prices

(Percentage Changes)

\begin{tabular}{lcc}
\hline Sector & Policy Only & Policy and Shocks \\
\hline 1. Food and Nonalcoholic Beverages & 1.5 & 3.6 \\
2. Tobacco and Alcoholic Beverages & 8.7 & 11.2 \\
3. Clothing & 7.0 & 6.8 \\
4. Housing & -.7 & -2.6 \\
5. Household & 5.0 & 4.4 \\
6. Medical Services & -1.9 & -2.1 \\
7. Transportation & -7.3 & -10.1 \\
8. Recreational Services & -4.1 & -4.2 \\
9. Other Services & -.5 & -.4 \\
& & \\
Correlation with 1986/1985 & .649 & .816 \\
Correlation with 1987/1985 & .374 & .421 \\
Correlation with Later Model & -.132 & .857 \\
& & \\
$\mathrm{R}^{2}$ for 1986/19885 & .023 & -.299 \\
$\mathrm{R}^{2}$ for 1987/1985 & -.451 & -.123 \\
$\mathrm{R}^{2}$ for Later Model & -.229 & .555 \\
\hline
\end{tabular}




\begin{tabular}{lcc}
\hline Sector & Policy Only & Policy and Shocks \\
\hline 1. Agriculture & -3.9 & 1.7 \\
2. Energy & -4.6 & -35.3 \\
3. Basic Industry & -4.3 & -8.7 \\
4. Machinery & -5.2 & -6.2 \\
5. Automobile Industry & -4.1 & -4.8 \\
6. Food Products & -4.0 & -1.1 \\
7. Other Manufacturing & -4.8 & -5.2 \\
8. Construction & -4.0 & -5.3 \\
& & \\
Correlation with 1986/1985 & .749 & .956 \\
Correlation with 1987/1985 & -.762 & .924 \\
Correlation with Later Model & .992 & .999 \\
& & \\
$\mathrm{R}^{2}$ for 1986/1985 & .509 & .263 \\
$\mathrm{R}^{2}$ for 1987/1985 & .396 & .816 \\
$\mathrm{R}^{2}$ for Later Model & .901 & .994 \\
\hline \hline
\end{tabular}


Industrial Activity Levels

(Percentage Changes)

\begin{tabular}{lcc}
\hline Sector & Policy Only & Policy and Shocks \\
\hline 2. Energy & -.8 & .5 \\
3. Basic Industry & 2.5 & 1.5 \\
4. Machinery & 3.9 & 2.8 \\
5. Automobile Industry & 3.6 & 6.0 \\
6. Food Products & -4.8 & -4.6 \\
7. Other Manufacturing & -3.4 & -2.9 \\
& & .290 \\
Correlation with 1986/1985 & .280 & .292 \\
Correlation with 1987/1985 & .301 & .983 \\
Correlation with Later Model & .934 & .953 \\
$\mathrm{R}^{2}$ for 1986/1985 & & .954 \\
$\mathrm{R}^{2}$ for 1987/1985 &. .191 & -.055 \\
$\mathrm{R}^{2}$ for Later Model & .778 & .079 \\
\hline
\end{tabular}


Major Macro Economic Variables

(Change From Benchmark as a Percentage of GDP)

\begin{tabular}{lcc}
\hline Variable & Policy Only & Policy \\
\hline Wages and Shocks \\
Business Income & -.56 & -.60 \\
Net Indirect Taxes & -1.21 & -1.16 \\
Correlation with 1986/1985 & 1.77 & 1.76 \\
Correlation with 1987/1985 & .9997 & .999 \\
Correlation with Later Model & .998 & .996 \\
$\mathrm{R}^{2}$ for 1986/1985 & .999 & .996 \\
$\mathrm{R}^{2}$ for 1987/1985 & .999 & .996 \\
$\mathrm{R}^{2}$ for Later Model & .992 & .989 \\
& .915 & .964 \\
Private Consumption & & \\
Private Investment & -1.24 & -1.53 \\
Government Consumption & 2.21 & .90 \\
Government Investment & -.21 & -.34 \\
Exports & -.07 & -.13 \\
Imports & -.44 & -.91 \\
Correlation with 1986/1985 & .25 & -2.01 \\
Correlation with 1987/1985 & .326 & .847 \\
Correlation with Later Model & .679 & .753 \\
$\mathrm{R}^{2}$ for 1986/1985 & .989 & .994 \\
$\mathrm{R}^{2}$ for 1987/1985 & .064 & .650 \\
$\mathrm{R}^{2}$ for Later Model & .418 & .513 \\
Indirect Taxes and Subsidies & .948 & .974 \\
Tariffs & & \\
Social Security Payments by Employers & 2.59 & 2.61 \\
Net Direct Taxes and Transfers & -.82 & -.85 \\
Government Capital Income & -.07 & -.12 \\
Government Spending & -.15 & .17 \\
Government Deficit & -.05 & -.05 \\
Correlation with 1986/1985 & -.29 & -.48 \\
Correlation with 1987/1985 & -1.79 & -2.24 \\
Correlation with Later Model & .940 & .882 \\
$\mathrm{R}^{2}$ for 1986/1985 & .717 & .793 \\
$\mathrm{R}^{2}$ for 1987/1985 & .982 & .999 \\
$\mathrm{R}^{2}$ for Later Model & .824 & .607 \\
\hline & .512 & .625 \\
& .944 & .978 \\
\hline
\end{tabular}


References

Andres, J.; Dolado, J. J.; Molinas, C; Sebastián, M.; and Zabalza, A. 1988. The influence of demand and capital constraints on Spanish unemployment. Working Paper SGPE-D-88005. Ministerio de Economfa y Hacienda.

Armington, P. 1969. A theory of demand for products distinguished by place of production. IMF Staff Papers 16, 159-78.

Auerbach, A. J., and Kotlikoff, L. J. 1987. Dynamic fiscal policy. Cambridge: Cambridge University Press.

Bergman, L.; Jorgenson, D. W.; and Zalai, E., Eds. 1990. General equilibrium modeling and economic policy analysis. Oxford: Basil Blackwell.

Bernheim, B. D.; Sholx, K. J.; and Shoven, J. B. 1991. Consumption taxation in a general equilibrium model: How reliable are simulation results? In National savings and economic performance, ed. B. D. Bernheim and J. B. Shoven. Chicago: University of Chicago Press.

Dervis, K; de Melo, J.; and Robinson, S. 1982. General equilibrium models for development policy. Cambridge: Cambridge University Press.

Devarajan, S., and Sierra, H. 1986. Growth without adjustment: Thailand, 1973-1982. Unpublished manuscript. World Bank.

Goulder, L. H., and Summers, L. H. 1989. Tax policy, asset prices, and growth: A general equilibrium analysis. Journal of Public Economics 38, 265-96.

Harrison, G. W., and Vinod, H. D. 1992. The sensitivity analysis of applied general equilibrium models: Completely randomized factorical sampling designs. Review of Economics and Statistics 74, 357-62.

Johansen, L. 1960. A multi-sectoral study of economic growth Amsterdam: North Folland. 
Jorgenson, D. W., and Yun, K.-Y. . 1990. Tax policy and U.S. economic growth. In General equilibrium modeling and economic policy analysis, ed. L. Bergman, D. W. Jorgenson, and E. Zalai. Oxford: Basil Blackwell.

Kehoe, T. J.; Manresa, A.; Noyola, P. J.; Polo, C.; and Sancho, F. 1988a. A general equilibrium analysis of the 1986 tax reform in Spain. European Economic Review 32: 334-42.

Kehoe, T. J.; Manresa, A.; Noyola, P. J.; Polo, C; Sancho, F; and Serra-Puche, J. 1985 a. Modelos de equilibrio general aplicado (MEGA): Un análisis del impacto del impuesto sobre el valor añadido (IVA) sobre la economia Española. Unpublished manuscript. Instituto de Estudios Fiscales.

1985b. A social accounting system for Spain: 1980. Working Paper 63.86. Departament d'Economia i d'Historia Economica, Universitat Autònoma de Barcelona.

1986a. A general equilibrium analysis of the indirect tax reform in Spain. Working Paper 66.86. Departament d'Economia i d'Historia Econòmica Universitat Autonoma de Barcelona.

- 1986b. Política economica i equilibri general. Quins són els efectes de l'IVA? Revista Econdmica de Catalunya 2: 76-81.

Kehoe, T. J.; Manresa, A.; Polo, C; and Sancho, F 1988b. Una matriz de contabilidad social de la economfa española. Estadistica Española 30: 5-33.

- 1989. Un análisis de equilibrio general de la reforma fiscal de 1986 en España. Investigaciones Economicas 13: 337-85.

Kehoe, T. J., and Serra-Puche, J. 1991. A general equilibrium appraisal of energy policy in Mexico. Empirical Economics 16: 71-93.

Mercenier, J., and Srinivasan, T. N., Eds. 1994. Applied general equilibrium and economic development. Ann Arbor: University of Michigan Press. 
Parmenter, B. R.; Meagher, G. A.; McDonald, D.; and Adams, P. D. 1990. Structural change in the 1970s: Historical simulations with ORANI-F. IAESR Working paper. University of Melbourne.

Piggott, J., and Whalley, J., Eḍ. 1985. New developments in applied general equilibrium analysis. Cambridge: Cambridge University Press.

Scarf, H. E., and Shoven, J. B. 1984. Applied general equilibrium analysis. Cambridge: Cambridge University Press.

Shiells, C. R., and Reinert, K. A. 1993. Armington models and terms of trade effects: Some econometric evidence for North America. Canadian Journal of Economics 26, 299-316.

Whalley, J. 1985. Hidden challenges in recent applied general equilibrium exercises. In New developments in applied general equilibrium analysis, ed. J. Piggott and J. Whalley, pp. 25-41. Cambridge: Cambridge University Press. 